\title{
Language Learning Approaches: Unity in Diversity
}

\author{
Mansoor Koondhar ${ }^{1 *}$, Elizabeth M.A ${ }^{1}$, Insaf A. Siming ${ }^{2}$, Tariq H. Umrani ${ }^{3}$ \\ ${ }^{1}$ Centre for Language Studies, University Tun Hussein Onn Malaysia \\ ${ }^{2}$ English Language Centre, QUEST, Nawabshah, Pakistan \\ ${ }^{3}$ Institute of English Language \& Literature, University of Sindh, Jamshoro, Pakistan
}

Corresponding Author: Mansoor Koondhar, E-mail: mansoorkoondhar@gmail.com

\section{ARTICLE INFO \\ Article history \\ Received: July 23, 2018 \\ Accepted: September 25, 2018 \\ Published: December 28, 2018 \\ Volume: 9 Issue: 6 \\ Advance access: November 2018}

Conflicts of interest: None

Funding: None

\section{Key words:}

Audio-Lingual Method,

Natural Method,

Communicative Method,

Second Language Learning,

Communication

\begin{abstract}
This is a conceptual paper based on the existing literature related to three famous language learning theories; Audio-lingual Method, Communicative method and the hypotheses of Stephen D. Krashen. These three schools of thought are not usually seen as similar or it is not common to find much literature regarding these theories having any common traits. The individual criticism on each of these theories focuses on many of their individual aspects but not on similarities among these three. The researchers however, after studying these theories closely, have been able to extract some striking similarities in spite of all the commonly known differences. The aim of this paper is to invite more focus and more research on similarities shared by these apparently independent schools of thought and consequently exploit the maximum fruits of these powerful theories. The findings suggest that the multiple similarities among the three schools of thought under study can jointly be named as one very vividly common trait: stress on the communicative skills involving listening and speaking to be the key towards successful language learning.
\end{abstract}

\section{INTRODUCTION}

The Audio-lingual Method, the Communicative Language Teaching and Natural approach of S.D Krashen are three separate language learning approaches very commonly referred to while talking about second language learning. Chronologically the Audio-lingual method was the first to emerge, during the days of world war two. It rose to great heights of fame due to its nature of quick yielding results; a sort of shortcut method (Chunsuvimol, \& Charoenpanit, 2017). In 1970's it was the rise of communicative pedagogy as many scholars turned their focus to it and produced a lot of literature. Communicative approach made its identity as Communicative language teaching (CLT) and is still in vogue (Fan, 2016). S.D. Krashen's ideas and his Natural approach have been subject to a vast criticism, yet strangely enough they have a huge fan club and Natural approach remains a very famous language learning approach till the day (Rohani, 2014).

The reason of writing this paper is to trace the elements of similarity among the three approaches under discussion as usually these three are not seen as similar to each other but the authors believe that they have a lot in common yet to be brought under the spotlight. The aim is to make use of the united force of these powerful schools of thought to channel them all together on one path for better results; learning language easily and effectively.

\section{GENERAL VIEWPOINT}

We are going to discuss the existing viewpoint prevalent in the existing literature regarding the three theories under discussion one by one. In nutshell, the three methods are not usually considered similar, however, their approach seems to have a common cause.

\section{Audio-lingual Method}

Chunsuvimol, \& Charoenpanit (2017) while focusing on Audio-lingual method assert that it was first used during the days of World War 2 for military purposes. During the war the countries participating in war needed to send their spies to enemy countries, an ages old tactic in wars. Before that, the spies needed to have an excellent command over the communicative skills of the target language in order not to risk their lives. The war is never a normal situation to allow the normal learning of a language. The then orthodox methods of language learning used to take a long time in language learning 
and the war situation would not allow for this. Consequently, as necessity is the mother of invention, the audio-lingual method came into existence. This method did produce the required results of language learning quite quickly.

The method was to carry out repeated drills of listening and speaking in the target language. It had more focus on the function rather than the form, parting ways with the typical grammar based learning. It was not only helpful at language learning but in many cases it was helpful in almost perfect acquisition of the target accent as well; though a language can be learnt very well without acquiring the target accent (Samawiyah, \& Saifuddin, 2016).

Audio-lingual method in its essence was not an educational activity as it was more a target based and a military drill with a notion of pressure on the learner. Later on however and here it is under discussion as an effective educational activity related to language learning. It yielded quicker results but because of having an un-educational air it was criticised and rejected by linguists and scholars for having its side effects as most of the shortcut methods usually have (Chunsuvimol, \& Charoenpanit, 2017).

\section{Communicative Method}

Communicative method gained popularity partly because of the failure of Audio-lingual method and partly because of the rise of cognitive pedagogy boosted by Chomsky's writings. Communicative method also like audio-lingual method pays primary attention to listening and speaking as in this method the key to learn a language is practically involving in communication. In this method the intention is to make the learning fun, an enjoyable process. This method focuses on the function of the language rather than telling what language is or the rules related to its learning (Fan, 2016).

Zhiming, \& Wee, (1998) maintain that this method differs from past language learning theories including audio-lingual method in many regards. It invites the involvement of student in learning process creating an environment of student centred classrooms. Almost all the past language learning theories prior to Communicative method have had teacher centred environment. According to this method, the goal of language education is the ability to communicate in the target language which is in contrast to previous views in which grammatical knowledge was commonly given the priority. It has a well designed syllabus for language teaching requiring teachers and students to use various strategies that may help. However, in spite of all the positives, communicative method doesn't go unchecked, free of criticism. Major argument of criticism over this method is that it is very hard to design a second language learning syllabus solely relying over the communicative activities without incorporating anything related to form, grammar. At least it would be very hard to convince teachers and parents to introduce such a syllabus (Fan, 2016).

\section{Krashen and his Natural Approach}

In Schekochihina's, (2016) opinion Krashen's Natural approach has been under discussion on a wide scale since its inception. His approach is quite contradictory to the past and present norms of language learning research. He believes that a language can only be learnt when the process takes place subconsciously. Any conscious attempt to learn it would only complicate the process further. He doesn't even use the term learning for the process of learning, he calls it acquisition. Learning to him is a conscious process on the other hand that can only help learn grammatical rules focusing on form of language. What he means by subconscious learning is learning unintentionally, acquiring language as a bi-product of interactive communication. The single most important factor responsible for language learning to him is the input (listening) that one receives. If there is no input there cannot be any output (product/speaking). This is what is the natural method of language learning, the way a child learns language. A child learns to communicate and understand language without any conscious efforts at least from his side. A child's learning is acquisition not learning (conscious). A child doesn't rely over rules of grammar for learning language.

Rohani, (2014) states that major criticism over Krashen's hypotheses is that what he says is untestable and thus undeniable. His separating learning from acquisition is quite an abstract idea. Acquisition not being conscious is his personal belief and how he defines it is totally subjective. Another controversial stance of him is that output (production) does not facilitate input (reception) in learning. Output is when you produce language in shape of speaking or writing. Input is when you receive language in shape of listening or reading. In simpler words, he asserts that speaking or writing cannot assist to learn listening or reading.

\section{AUTHORS' VIEWPOINT}

As it has been mentioned earlier that the purpose of writing this paper is to find similarities between the three schools of thought under discussion, the authors disagree with any viewpoint identifying these three theories different from each other with no similarity. The authors after studying the aims and objectives of the three theories believe that there are a lot of similarities shared by them, not much discussed. In order to share the similarities, we make cross pairs of the three approaches to make the process easier.

\section{Audio-lingual Method and Communicative Method}

There are many researchers who directly or indirectly have considered Audio-lingual and communicative methods to be on the same page as they have written articles specifically focusing on these two approaches jointly i.e. (Nita, \& Syafei, (2012), Rahman, \& Begum, (2006), Te-jung, (2009), Ögeyik, \& Dogruer, (2009), Tambunan, \& Gintings, (2012), Ghofur, (2016), Ghofur, et al., (2017). To conclude their ideas it can be said that the goal of both the methods is same, communicative competence through practical interaction. The two methods rely over the two communication skills, i.e. listening and speaking considering them the key towards language learning. Listening is what leads to speaking according to Audio-lingual method, more like Natural method, however communicative method pays equal attention to listening and 
speaking both. There are some other differences as well regarding the curriculum and their strategies, as Audio-lingual method is always seen in a military context more than an educational one and communicative method has a large number of educationists and linguists backing it. However, when the question is regarding achievement or target, the answer is same from both sides: ability to communicate effectively. And listening has a big role to play in achieving the target according to both the approaches. This makes both the approaches synonymous.

\section{Audiolingual Method and Krashen's Natural Approach}

There has not been much literature published regarding the similarities between Audio-lingual method and the Natural approach and a majority of literature regarding similarities among the three approaches under discussion has focused on similarities between Audio-lingual method and Communicative method rather. However, the authors have been able to find a couple of papers (Bai-yu, (2001) and Matamoros-González et al., 2017) who have found multiple similarities between Audio-lingual method and Natural approach.

Matamoros-González et al., (2017) while enlisting similarities between various language learning approaches found Audio-lingual method and Natural approach similar in many features. They found the two approaches similar regarding few features related to materials, techniques and students' role. Particularly according to their exhaustive list, they found Books, Audio, visual and Audio-visual materials to have been mutually used by the two theories. Regarding the techniques, they found dialogues and listening activities mutually used. Finally regarding the role of students, they found that both the approaches require active participation of students.

Bai-yu, (2001) concludes that the two theories are very much similar. Audio-lingual method though focuses on listening and speaking both on the contrary to Natural method, however, it considers listening as key towards speaking as listening was the primary method of language learning according to the gospel of Audio-lingual method. This listening is what is termed as 'input' by Krashen and has central importance in the Natural method regarding language learning. So there is a similarity of focus shared by the two methods. Though Natural approach does not consider speaking to play any significant role in language learning, contrary to Audio-lingual method, however, Audio-lingual method also gives speaking a secondary priority. So, both the approaches have their primary focus on listening (input) and consider it to be pivotal for language learning.

\section{Communicative Method and Krashen}

The last possible cross pair of the three approaches is of Communicative method and Natural approach of Krashen. Hinkel, \& Fotos, (2002, p. 4) in the opening chapter of their book discuss different past language learning theories. After having discussed Grammar translation method and Audio-lingual method they write about Communicative Language Teaching and the Natural approach of Krashen being similar theories as they discuss them jointly in the same section under the heading of 'Communicative Language Teaching. In fact, they even consider Krashen to be responsible for the rise of Communicative approaches in 1980's.

Ellis, (2002) is also of the same opinion in his article. He also puts Krashen's approach and Communicative language teaching together considering them on the same footing. Zimmerman (1997, p. 15) in his book quotes Krashen and Terrell, (1983, p 17) for calling Natural approach of Krashen to be similar to contemporary Communicative approaches of language learning. So here we have a case of Krashen himself certifying his Natural approach to be Communicative in essence.

Saito, (2013) in his paper has discussed differences and similarities shared by the two methods. However, despite the differences between the two, he in his concluding remarks talks about the similarities in these words, "Emergent from the above reflection is that both NA and CLT share quite a few principles in the approach, design, and procedure levels".

Apart from the above mentioned literature, some more literature focusing jointly on the Communicative language teaching and the Natural approach of Krashen can be found on internet, i.e. (Fand, 1985, Fernandes, 1989, Hughes, 1998). It has already been mentioned in the abstract section that it would be a minority of literature to consider these theories similar; so much of the literature is on the other side. However, the meagre quantity of the literature that has been quoted is enough to make the point as intended and is suggestive of Krashen's Natural approach and Communicative pedagogy being on the same footing.

\section{CONCLUSION}

It is never easy to defend a tendency going opposite to the common trends, so was the case with this paper. It was found while preparing this paper that it is out of fashion currently to consider the three approaches under discussion similar. The differences among the three approaches may be found on many fronts. However, the authors have come up with references reasoning logically that if there are differences methodologically among the three approaches, they are at the same time on the same page, as long as their cause is considered. All the three approaches unanimously initiate their methods with listening to be the root cause of communication without which learning language would be impossible. Even reading and writing would require verbal input to assist language learning.

Similarities among the three approaches were realized by making cross pairs of the three approaches which means quite logically that if A matches B and B matches $\mathrm{C}$ it means all match with each other. So it justifies that the three approaches are similar to each other.

This effort is expected to be a stepping stone to lead towards more research on similarities shared by these three approaches. These three approaches have their followers and are in practice throughout the world. What the authors of this paper would like to recommend is that efforts should be made to devise a joint method through the amalgam of these three 
approaches which can be named as Natural Communicative Method (NCM). NCM can pave the way for a better, faster and more intelligent approach of second language learning.

\section{ACKNOWLEDGMENT}

Funding for this research was provided by University Tun Hussien Onn Malaysia under the TIER 1 grant (Vot H193)

\section{REFERENCES}

Bai-yu, C. H. E. N. (2001). The" Input-Output" Theory and Audio-Lingual-Visual Approach [J]. Journal of Guangzhou University, 4, 015.

Chunsuvimol, B., \& Charoenpanit, P. (2017). Effectiveness of the Audiolingual Method: A Further Synthesis of Research Through 2015.

Fan, J. I. N. (2016). A Brief Introduction to Communicative Language Teaching. 海外英语, 17, 106.

Krashen, S. D., \& Terrell, T. D. (1983). The natural approach: Language acquisition in the classroom.

Ellis, R. (2002). The place of grammar instruction in the second/foreign language curriculum. New perspectives on grammar teaching in second language classrooms, 17-34.

Ghofur, A. (2016). THE EFFECT OF COMMUNICATIVE LANGUAGE TEACHING METHOD AND THE AUDIO-LINGUAL METHOD FOR STUDENTS'ENGLISH SPEAKING SKILL.

Ghofur, A., Degeng, I. N. S., Widiati, U., \& Setyosari, P. (2017). The Effect Of Communicative Language Teaching And Audio-Lingual Method On English Speaking Skill Across Different Learning Styles. KnE Social Sciences, 1(3), 1-7.

Hinkel, E., \& Fotos, S. (2002). From theory to practice: A teacher's view. New perspectives on grammar teaching in second language classrooms, 1-12.

Fand, R. (1985). The compatibility of the Natural Approach and the Communicative Approach. Cross Currents, 12(2), 1-14.

Fernandes, M. H. B. (1989). Utilization of the Natural Learning Sequence Within Communicative Syllabus Implementation(Doctoral dissertation, University of Newcastle).

Matamoros-González, J. A., Rojas, M. A., Romero, J. P., Vera-Quiñonez, S., \& Soto, S. T. (2017). English Language Teaching Approaches: A Comparison of the Grammar-translation, Audiolingual, Communicative, and Natural Approaches. Theory and Practice in Language Studies, 7(11), 965-973.
Nita, S. A., \& Syafei, A. F. R. (2012). Involving Audio-lingual Method (ALM) and Communicative Language Teaching (CLT) in Teaching Speaking Skill at Junior High School. Journal of English Language Teaching, 1(1), 65-73.

Ögeyik, M. C., \& Dogruer, S. (2009). An Evaluation of the Communicative Approach and Audio-Lingual Method in Teaching Grammar in a Private High School in Turkey. Language in India, 9(3).

Rahman, M. F., \& Begum, M. (2006). Audio-Lingual Method: A Rethinking on the Effective Use of its Principles in Communicative Language Classroom. Teacher's World, $28,29,31$.

Rohani, R. (2014). KRASHEN ${ }^{e e}$ S LANGUAGE ACQUISITION HYPOTHESES: A CRITICAL REVIEW. In UNNES International Conference on ELTLT (English Language Teaching, Literature, and Translation) (pp. 660-665).

Samawiyah, Z., \& Saifuddin, M. (2016). Phonetic Symbols through Audiolingual Method to Improve the Students' Listening Skill. Dinamika Ilmu: Jurnal Pendidikan, 16(1), 35-46.

Saito, A. (2013). Revisiting Natural Approach and Communicative Language Teaching: A Reflection through Richards and Rodgers' Model of Method. 八戸工業大学紀要, 32, 175-181.

Schekochihina, S. V. (2016). SOME PRINCIPLES IN SECOND LANGUAGE ACQUISITION FROM STEPHEN D KRASHEN. In 21 век: фундаментальная наука $и$ технологии (рp. 59-61).

Hughes, C. L. (1998). The natural approach: a great landmark in the exploration of communicative language teaching methods (Doctoral dissertation, University of Southern Mississippi).

Tambunan, I. R., \& Gintings, E. M. (2012). The effect of communicative and audio lingual Method On Student's Conversational Achievement. Linguistica, 1(1).

Te-jung, L. O. (2009). A Study on the Application of Audio-Lingual Method and Communicative Approach in Mandarin Teaching at the Elementary Level. Journal of College of Chinese Language and Culture of Jinan University, $1,008$.

Zhiming, B., \& Wee, L. (1998). Functionalism in Education: A Critique of the Communicative Approach to Language Teaching. Text in Education and Society, 91.

Zimmerman, C. B. (1997). Historical trends in second language vocabulary instruction. Second language vocabulary acquisition, 5-19. 